\title{
Effect of Packaging Material on the Shelf Life of Drinking Water
}

\author{
Neelima Shukla \\ Narmada Agro Foods, Crystal Packaged Drinking Water ,Shivnagar ,Jabalpur(M.P.) ,India
}

\begin{abstract}
All living things need water. The Earth is full of water. Water is the most essential element, next to air, to our survival. Water makes up more than two thirds of the weight of the human body, and without it, we would die in a few days. Water is important to complete daily life and to maintain our body healthy.Packaged Drinking Water can be described as any product, including natural spring or well water taken from municipal or private utility systems or other water.Distilled water or any of the fore going to which chemicals may be added and which are put into sealed bottles ,packages or other containers to be sold for domestic consumption or culinary use. In this study, various type of samples packed in bottles as well as pouches were taken and the effect of their packaging material was seen.
\end{abstract}

Keywords: Packaged Drinking Water, Natural Spring

\section{Introduction}

Water is essential for life. The amount of drinking water required is variable ,It depends on physical activity, age, health issues and environmental conditions. Typically in developed countries ,tap water meets drinking water quality standards even though only a small proportion is actually consumed or used in food preparation, Water may also be unacceptable due to levels of toxins or suspended solids .Reduction of water borne diseases and development of safe water resources is a major public heaith goal in developing countries. Fresh drinking water means the pure water which is free from any bacteria, microbes, chemicals and thus odorless, colorless crystal clear water is packaged in a sterilizes pet bottle with a sealed cap. This water can be carried to any place and it remains fresh and pure up to 2-3 months. This water also known as mineral water. Water is not important to human beings but also for every living thing needs it to live. It has helped from the Earth as we know it and it covers over 70\% of the earth. Even where there is land, much of it is covered by ice, which is obviously just solid water.Water is important in homeostasis process to maintain the relatively constant temperatures with in the body. This is important because sudden changes in temperature, which may upset metabolic relations in cell, are avoided .These chemical reactions are allowed to take place with in a narrow temperature range so that rates of reactions are more constant.Water has been called a universal solvent because of it polarity. This means many compounds, whether ionic ,polar or covalent will dissolve in it therefore more reactions take place while in solution with water .Human digestion will only dissolve soluble foods , meaning large starch molecules must be broken down into soluble sugars also many organisms living in water ,spend most of their time under water, yet they require oxygen to respire and as water is such a good solvent, the required oxygen is dissolved in water.

\section{History of Bottled water industry}

The earliest bottled water company was founded in the US in the middle of the $19^{\text {th }}$ century. In 1845 , the Ricker family of maine bottled and sold water from a so far undefined source .Their small operation quickly grew ,capitalizing on the springs supposed medicinal properties, eventually because the poland springs water company .Mirroring the Ricker success ,in 1905 the Ozarka spring water company was founded in Eureka springs. Arkansas since (Mark Miller 2006) then bottled water landscape has expanded .tremendously. This expansion has come mostly recently, and it seems to be the acceleration of a slowly expanding industry between the early part of the 20 th century and its end ,there was little activity in the bottled water industry Finlayson D.(2005).

Market analysis of Packaged Drinking Water on Environment.

(i) $80 \%$ of the diseases in India are water -borne.

(ii) $60-80 \%$ children suffer from water -borne diseases.

(iii) 50,000 people die every day due to water contamination.

(iv) India has 17 million cases of viral hepatitis and,

(v) Eight million cases of typhoid every year.

All this happens due to water contamination in fact, There are three types of water contamination as explained below:

(1) Physical Contamination: Caused due to contaminants like mud ,sand ,odour,colour, algae, fungus, herminths etc. 
(2) Chemical Contamination: Caused due to insecticides, pesticides, oils, excess of ions , unwanted minerals.

(3) Microbiological Contamination: Caused by bacteria, viruses of other unicellular organisms.

Bacteriological Water Analysis: out what sort of bacteria they are.It represents one aspect of water quality .It is a microbiological analytical procedure which uses samples of water and from these samples determines the concentration of bacteria it is then possible to draw inferences about the suitability of the water for use from these concentrations .This process is used ,for example ,to routinely confirm that water is safe for human consumption or that bathing and recreational waters are safe to use.(U.S. Environmental Protection Agency (E.P.A.),Washington ,D.C. ,October 2002))

\section{Materials and Methods}

Collection of samples : Ten fresh samples of water packed with Polyethylene film and ten with Bottle were collected to check the shelf life of different types of Microbiological analysis.

Physical Parameters: Colour, Odour and Taste of the sample were tested.

Chemical Parameter: $\mathrm{p} \mathrm{H}$ of the sample was tested.

Microbiological Parameters : Total plate count was done by membrane filter technique . The sample $250 \mathrm{ml}$. ( for pouch and $1 \mathrm{ml}$. for bottle) was passed through membrane filter assembly which had nitrocellulose filter paper after that filter paper was kept on petridishes containing plate count agar media and incubated at $20^{\circ} \mathrm{C}$ and $37^{\circ} \mathrm{C}$ for 24 hours after incubation ,colonies were counted.

Total coliform count: Nitrocellulose Filter paper was kept on petri dishes containing VRBL medium and incubated at $37^{\circ} \mathrm{C}$ for 24 hours.

Yeast and Moulds Count: Nitrocellulose filter paper was kept on Potato -Dextrose Adar media and incubated at $28{ }^{\circ} \mathrm{C}$ for 72 hours.

E.coli: Nitrocellulose Filter was kept on Petridish containing Eosine Methylene Blue Agar Mediumand incubated at $37^{\circ} \mathrm{C}$ for 24 hours.

Pseudomonas aeruginosa: Nitro cellulose filter paper was kept on Pseudomonas isolation Agar and incubated at $37^{\circ} \mathrm{C}$ for 24 hours.

S.aureus: Nitro cellulose Filter Paper kept on Baird Parker Agar and incubated at $37^{\circ} \mathrm{C}$ for 24 hours.

After incubation ,colonies were counted as CFU/250 mi. and CFU/l. and recorded .This procedure was repeated up to two months for pouches and seven months for bottles.

\section{Results and discussion}

After seven months study, all the physical parameters like color, odors taste and turbidity were ok for both type of samples and there was no growth of E.coli, Coliforms, Pseudomonas aeruginosa, Yeasts and Moulds were absent. After two months, the values of Total plate count of Pouch Packed Samples were more than limits where as values of Bottled water Samples were more than six months.

This happens because the thickness of Bottle is more than polyfilm .Sometimes pouch packed water retains odor of things which are kept with them and bacteria may also contaminate this water easily that is why it can not be kept longer.

Table 1 and 2 show the changes in $\mathrm{p} \mathrm{H}$ of samples and table and 3 and show the shelf life of both samples. In pouch packed samples ,no. of bacteria increased after one month where as in bottled water ,no. of bacteria reach beyond limits after six months. It indicates the expiry of packaged drinking water this is due to the packaging material.

Table-1. Changes in p H of Pouch Packed Sample Limit : 6.65-8.85

\begin{tabular}{|l|l|l|l|}
\hline S.No. & Sample Id & p H \\
\hline & & I st Month & II nd Month \\
\hline 1 & P1 & 6.83 & 7.12 \\
\hline 2 & P2 & 6.91 & 7.28 \\
\hline 3 & P3 & 6.78 & 6.92 \\
\hline 4 & P4 & 6.95 & 7.03 \\
\hline 5 & P5 & 7.11 & 7.21 \\
\hline 6 & P6 & 6.89 & 6.91 \\
\hline 7 & P7 & 7.09 & 7.13 \\
\hline 8 & P8 & 7.2 & 7.34 \\
\hline 9 & P9 & 7.06 & 729 \\
\hline 10 & P10 & 6.97 & 6.98 \\
\hline
\end{tabular}


Table-2 Changes in $\mathrm{p} H$ of Bottled Samples

\begin{tabular}{|l|l|l|l|l|l|l|l|l|}
\hline S.No. & $\begin{array}{l}\text { Sample } \\
\text { ID }\end{array}$ & I st Month & II nd Month & $\begin{array}{l}\text { III rd } \\
\text { Month }\end{array}$ & IV th Month & $\begin{array}{l}\text { V th } \\
\text { Month }\end{array}$ & $\begin{array}{l}\text { VI th } \\
\text { Month }\end{array}$ & VII th Month \\
\hline 1 & B1 & 6.82 & 7.08 & 7.12 & 7.22 & 7.28 & 7.34 & 7.42 \\
\hline 2 & B2 & 6.9 & 6.98 & 7.01 & 7.04 & 7.11 & 7.19 & 7.3 \\
\hline 3 & B3 & 7.05 & 7.12 & 7.14 & 7.26 & 7.3 & 7.38 & 7.45 \\
\hline 4 & B4 & 6.97 & 6.99 & 7.06 & 7.13 & 7.25 & 7.3 & 7.52 \\
\hline 5 & B5 & 7.18 & 7.29 & 7.29 & 7.32 & 7.41 & 7.48 & 7.63 \\
\hline 6 & B6 & 7.33 & 7.34 & 7.42 & 7.45 & 7.49 & 7.56 & 8.1 \\
\hline 7 & B7 & 6.81 & 6.85 & 6.88 & 6.97 & 6.99 & 7.04 & 7.19 \\
\hline 8 & B8 & 6.9 & 6.91 & 6.95 & 6.99 & 7.03 & 7.16 & 7.2 \\
\hline 9 & B9 & 6.99 & 7.03 & 7.06 & 7.06 & 7.1 & 7.12 & 7.31 \\
\hline 10 & B10 & 7.07 & 7.09 & 7.13 & 7.15 & 7.19 & 7.27 & 7.46 \\
\hline
\end{tabular}

Table -3. Shelf Life of Pouch Packed Water Limit: Total plate Count at $20^{\circ} \mathrm{C} 100$ colonies at $37^{\circ} \mathrm{C} 20$ colonies Other Microorganisms should be absent

\begin{tabular}{|l|l|l|l|l|l|}
\hline \multirow{2}{*}{ S.No. } & \multirow{2}{*}{ Sample Id } & \multicolumn{2}{|c|}{ Total Plate count $\left(\right.$ at 20 ${ }^{\circ}$ C) } & \multicolumn{2}{l|}{ Total Plate Count (at 37 $\left.{ }^{\mathbf{}} \mathbf{C}\right)$} \\
\cline { 3 - 6 } & & Ist Month & II nd Month & Ist Month & II nd Month \\
\hline 1 & P1 & 12 & 106 & 4 & 22 \\
\hline 2 & P2 & 36 & 110 & 15 & 27 \\
\hline 3 & P3 & 5 & 92 & 6 & 18 \\
\hline 4 & P4 & 14 & 120 & 2 & 10 \\
\hline 5 & P5 & 12 & 103 & 12 & 31 \\
\hline 6 & P6 & 41 & 119 & 6 & 29 \\
\hline 7 & P7 & 18 & 125 & 18 & 47 \\
\hline 8 & P8 & 61 & 196 & 8 & 17 \\
\hline 9 & P9 & 9 & 182 & 2 & 25 \\
\hline 10 & P10 & 25 & 137 & 13 & 56 \\
\hline
\end{tabular}

Table -4. Shelf Life of Bottled Packed Water Limit: Total plate Count at $20^{\circ} \mathrm{C} 100$ colonies at $37^{\circ} \mathrm{C} 20$ colonies

Other Microorganisms should be absent

\begin{tabular}{|c|c|c|c|c|c|c|c|c|c|c|c|c|c|c|c|}
\hline \multirow[t]{2}{*}{ S.No. } & \multirow{2}{*}{$\begin{array}{l}\text { Sample } \\
\text { Id }\end{array}$} & \multicolumn{6}{|c|}{ Total Plate Count (at $20^{\circ} \mathrm{C}$ ) } & & \multicolumn{7}{|c|}{ Total Plate Count (at $37^{\circ} \mathrm{C}$} \\
\hline & & $\begin{array}{l}\text { Ist } \\
\text { Month }\end{array}$ & $\begin{array}{l}\text { II nd } \\
\text { Month }\end{array}$ & $\begin{array}{l}\text { III rd } \\
\text { Month }\end{array}$ & $\begin{array}{l}\text { IV th } \\
\text { Month }\end{array}$ & $\begin{array}{l}V \text { th } \\
\text { Month }\end{array}$ & $\begin{array}{l}\text { VI th } \\
\text { Month }\end{array}$ & $\begin{array}{l}\text { VII th } \\
\text { Month }\end{array}$ & $\begin{array}{lr}\text { I r st } \\
\text { Month }\end{array}$ & $\begin{array}{l}\text { II nd } \\
\text { Month }\end{array}$ & $\begin{array}{l}\text { III rd } \\
\text { Month }\end{array}$ & $\begin{array}{l}\text { IV th } \\
\text { Month }\end{array}$ & $\begin{array}{l}V \text { th } \\
\text { Month }\end{array}$ & $\begin{array}{l}\text { VI th } \\
\text { Month }\end{array}$ & $\begin{array}{l}\text { VII th } \\
\text { Month }\end{array}$ \\
\hline 1 & $\mathrm{~B} 1$ & 10 & 18 & 21 & 26 & 81 & 96 & 102 & 2 & 6 & 11 & 14 & 16 & 20 & 53 \\
\hline 2 & B2 & 2 & 5 & 5 & 6 & 10 & 18 & 27 & 1 & 1 & 4 & 10 & 11 & 15 & 18 \\
\hline 3 & B3 & 9 & 12 & 15 & 22 & 36 & 41 & 159 & 8 & 11 & 13 & 16 & 17 & 19 & 25 \\
\hline 4 & B4 & 3 & 3 & 17 & 29 & 56 & 71 & 101 & 1 & 1 & 9 & 10 & 10 & 16 & 16 \\
\hline 5 & B5 & 32 & 41 & 45 & 52 & 63 & 79 & 99 & 5 & 7 & 8 & 12 & 18 & 19 & 31 \\
\hline 6 & B6 & 51 & 54 & 72 & 75 & 89 & 93 & 116 & 3 & 3 & 3 & 10 & 11 & 15 & 22 \\
\hline 7 & B7 & 29 & 37 & 39 & 44 & 62 & 71 & 83 & 0 & 3 & 8 & 8 & 10 & 16 & 27 \\
\hline 8 & B8 & 65 & 71 & 77 & 83 & 88 & 96 & 135 & 2 & 2 & 9 & 9 & 13 & 19 & 21 \\
\hline 9 & B9 & 24 & 29 & 33 & 37 & 49 & 56 & 62 & 9 & 12 & 12 & 11 & 18 & 18 & 19 \\
\hline 10 & B10 & 14 & 22 & 26 & 31 & 58 & 79 & 40 & 1 & 2 & 2 & 4 & 7 & 8 & 21 \\
\hline
\end{tabular}

\section{References}

[1]. Mark Miller ,"Bottled water ; why is it so big? Causes for the rapid growth of bottled water industries ."Honors thesis ,presented to the honors committee of texas state university.san Marcos, May 2006.

[2]. Finlayson D. (2005). Market development of bottled waters in D. senior and N.Dege (2 $2^{\text {nd }}$ ed.) .Tech of bottled water P (6) UK Blackwell publishing.

[3]. Kloos W.E. systematic and the natural history of Staphylococci .In Staphylococci ,J. Appl.Bacteriol Symp. Suppl. 69 1990, p.p. 25 s.37 s. and Bergey's manual of determinative bacteriology, $9^{\text {th }}$ edn.1994.

[4]. IS 5404:1984 Code of practice for handling of samples for microbiological analysis (first revision).

[5]. IS 6850:1973 Agar,Microbiological grade.

[6]. ISO/IS 11133-2:2003 Microbiology of food and animal feeding stuffs - Guidelines on preparation and production of culture media Part -1 : General guidelines of quality assurance for the preparation of culture media in the laboratory.

[7]. ISO 6887 (all parts),Microbiology of food and animal feeding stuffs -Preparation of test samples, initial suspention and decimal dilutions for microbiological examination.

[8]. ISO 7218:1994 Microbiology of food and animal feeding stuffs- General rules for microbiological examination.

[9]. U.S. Environmental Protection Agency (EPA),Washington ,D.C. (October 2002).’Method 1680 Faecal coliforms in Biosolids by multiple tube ferm" producers"Draft document no. EPA-821 -

[10]. Journal of the European ceramic society 31 (15) : 2877-2885.doi: 10.1016/j.jeruceram soc.2011.07.007. 